\title{
International flagship stores: an exploration of store atmospherics and their influence on purchase behaviour
}

DOI:

10.1504/IJBG.2019.097392

\section{Document Version}

Final published version

Link to publication record in Manchester Research Explorer

\section{Citation for published version (APA):}

Blazquez, M., Boardman, R., \& Xu, L. (2019). International flagship stores: an exploration of store atmospherics and their influence on purchase behaviour: An exploration of store atmospherics and their influence on purchase behavior. International Journal of Business and Globalisation, 22(1, 2019), 110-126.

https://doi.org/10.1504/IJBG.2019.097392

\section{Published in:}

International Journal of Business and Globalisation

\section{Citing this paper}

Please note that where the full-text provided on Manchester Research Explorer is the Author Accepted Manuscript or Proof version this may differ from the final Published version. If citing, it is advised that you check and use the publisher's definitive version.

\section{General rights}

Copyright and moral rights for the publications made accessible in the Research Explorer are retained by the authors and/or other copyright owners and it is a condition of accessing publications that users recognise and abide by the legal requirements associated with these rights.

\section{Takedown policy}

If you believe that this document breaches copyright please refer to the University of Manchester's Takedown Procedures [http://man.ac.uk/04Y6Bo] or contact uml.scholarlycommunications@manchester.ac.uk providing relevant details, so we can investigate your claim.

\section{OPEN ACCESS}




\title{
International flagship stores: an exploration of store atmospherics and their influence on purchase behaviour
}

\section{Marta Blazquez*, Rosy Boardman and Luyu Xu}

School of Materials,

University of Manchester,

Oxford Road, Manchester, M13 9PL, UK

Email: marta.blazquezcano@manchester.ac.uk

Email: rosy.boardman@manchester.ac.uk

Email: edenyytytzc@126.com

*Corresponding author

\begin{abstract}
Flagship stores are luxury retailers' most prestigious market entry method and serve as impressive representations of their brand image. However, there is a lack of extant research investigating how the holistic experience created in luxury flagship stores has an effect on consumers' purchase behaviour. This study aims to fill this gap in the academic literature by using a qualitative methodology to explore how the atmospheric cues in luxury flagship stores influence consumers' impressions of the brand and, ultimately, their impulse and non-impulse purchase behaviour. The findings show that atmospheric cues and design features have a significant impact on the perceived brand image and on both impulse and non-impulse purchase behaviour. Furthermore, the results show that the most influential atmospheric cues on purchase behaviour are the customer service provided, followed by the product displays, the layout of the store and the design and experience of the fitting rooms.
\end{abstract}

Keywords: flagship stores; store atmospherics; international retail; in-store experience; luxury retailing; purchase behaviour.

Reference to this paper should be made as follows: Blazquez, M. Boardman, R. and Xu, L. (2019) 'International flagship stores: an exploration of store atmospherics and their influence on purchase behaviour', Int. J. Business and Globalisation, Vol. 22, No. 1, pp.110-126.

Biographical notes: Marta Blazquez is a Lecturer in Fashion Marketing at the University of Manchester. Her research interests include omni-channel and experiential retail, in-store technology, social media marketing, mobile marketing and consumer behaviour. She has published in leading journals and contributed to edited books. She holds her BA in Advertising and PR and has held senior positions in advertising and marketing.

Rosy Boardman is a Lecturer in Fashion Business at the University of Manchester. Her research interests include online retailing, website design, omni-channel retail, social media marketing and e-commerce and consumer behaviour. She completed her PhD in Online Retailing and Website Design using eye tracking technology and qualitative interviews. 
Luyu $\mathrm{Xu}$ completed her MSc in International Fashion Retailing at the University of Manchester. Her research interest focuses on experiential retail and customer purchase behaviour. She moved from academia and is establishing a career in the marketing industry in an international investment company in London.

\section{Introduction}

The accelerated process of globalisation and technology innovation is putting international retailing under a lot of pressure. The fashion sector is regarded as one of the most prolific sectors in terms of internationalisation strategies with fashion retailers expanding continuously into foreign markets (Moore et al., 2010). Indeed, the internationalisation of markets has led to fierce competition in the luxury fashion sector (Rath et al., 2012). Therefore, fashion retailers need to find ways to connect to their customers and offer them an attractive proposition (Blázquez, 2014).

One of the formats that have been central to the internationalisation strategies of fashion retailers is the flagship store, however, its importance has been neglected in the literature until recently (Moore et al., 2010). The past few years have seen an increase in luxury fashion retailers opening flagship stores in major cities worldwide in order to strengthen and control their brand image and the way that it is perceived by consumers, to enhance their brand identity and provide an enjoyable experience for customers (Manlow and Nobbs, 2013). Brand image reflects the strength and uniqueness of brand associations held by a consumer, which comprehensively carries and identifies the consumers' overall meaning of the brand (Choi, 2014; John, 2016) whilst brand identity is concerned with the overall presentation and communication of the brand to the market and can be interpreted as the brand's positioning (Kapferer, 2008; Urde, 2013). As a result of the strong brand experiences facilitated for consumers, flagship stores have a more powerful impact on brand attitude, brand attachment and brand equity compared to stores (Dolbec and Chebat, 2013).

The flagship store is a key way for the brand to enter into a market, especially international markets, as they attract a lot of media attention (Moore et al., 2010). Major fashion brands have expanded from the main fashion capitals in the world to other capital cities through flagship stores (Moore et al., 2010). However, whilst flagship stores have traditionally been regarded as functioning more as brand image representatives than sales channels, entering a new market means that both functions should be balanced. Yet, no previous research addresses this particular issue.

Therefore, the prevalence of luxury fashion retailers on the global stage emphasises the need for further investigation into the flagship store format as it is the most prevalent, and it continues to increase in number and strategic significance in the fashion sector (Manlow and Nobbs, 2013; Moore et al., 2010). This research aims to explore how flagship stores can be used as part of a global marketing and management strategy by delivering a superior brand experience to customers as well as increasing sales for retailers. To fulfil this aim, the research investigates how the atmospheric cues in luxury apparel retailers' flagship stores have an impact on the perceived store experience and customer purchase behaviours. 


\section{The concept of the flagship store}

The flagship store format refers to a brand's own store that is located in a large outlet in a prominent area, that offers the widest and most in-depth product assortment and comprises of a high quality store environment which serves to communicate the brand's position and values (Manlow and Nobbs, 2013). The format was first introduced in retailing in the 1970s and, since the 1990s, the number of branded flagships has rapidly grown all over the world (Kozinets et al., 2002; Kent and Brown, 2009). The flagship store conveys both a strategic and an operational role having a mixed function between communication and sales (Manlow and Nobbs, 2013). They are present at all levels of the fashion sector from high street retailers (e.g., Zara or Topshop) to low-cost retailers (e.g., Primark). However, flagship stores are most prevalent in the luxury sector and are commonly used as part of luxury retailers' internationalisation strategies (Moore et al., 2010; Manlow and Nobbs, 2013) making them the most relevant type of flagship stores to study in order to fulfil the research objectives.

Flagship stores are differentiated from other international stores by their sheer scale and design, their location and their higher setup and operating costs (Moore et al., 2010). Indeed, the large size of flagship stores, and their location within the premium shopping streets of key cities serve to enhance the brand's reputation and sense of status (Moore et al., 2010). Furthermore, previous research has found that the close proximity of so many luxury retailers' flagship stores has resulted in the creations of a 'luxury sense of place' in that area (Arrigo, 2015).

Flagship stores can be distinguished by three main characteristics: Firstly, they consist of a single brand, secondly, the brand manufacturer owns them and thirdly, they are operated with the intention of building or reinforcing the brand image rather than selling the product (Kozinets et al., 2002). Hence, despite sales figures being important as a result of the elevated cost that the flagship represents, flagship stores are also used in international markets as a showcase for the brand (Moore et al., 2010). Indeed, flagship stores are considered to represent the peak of branding strategies (Dolbec and Chebat, 2013).

Flagship stores, as places of entertainment, require detailed attention to be placed on the aesthetics and the processes by which consumers take meaning out of their experience of the place. For Kozinets et al. (2002, p.28), these are complex experiential places that retailers use to reassure consumers by combining the "ordinary with the mythic, the profane with the sacred, and the innovative with the familiar".

Branding through flagship stores is "a means not only of promotion and advertising for the luxury brand but a way to engage emotionally with consumers through the creation of meaningful experiences that may ultimately lead to relationships" [Manlow and Nobbs, (2013), p.50]. Indeed, Brengman and Willems (2003) suggest that decisions on store design generate consumer awareness of the brand identity. These decisions include the creation of spacious stores, shelf design or comfortable furniture that is going to increase the high-status and luxury image of the goods and of the brand (Manlow and Nobbs, 2013). 


\section{Luxury retailing in international markets}

The definition of luxury fashion brands can be challenging due to the multifaceted, ambivalent and subjective nature of the luxury concept (Phau and Prendergast, 2000; Heine and Phan, 2011). Luxury items are identified by the attributes of high price, high quality, aesthetics, rarity, extraordinariness and symbolism (Kapferer and Bastien, 2008). Luxury items are rare and harder to access than other goods (Kapferer and Bastien, 2012) and they can be described by three characteristics: they are made using a high level of craftsmanship, they incorporate strong artistic content and, even if they have national characteristics, they maintain an international profile by being available in the world's fashion capitals (Chevalier and Mazzalovo, 2012).

Luxury goods satisfy different types of consumer needs including functional needs, psychological or symbolic needs, and emotional or experiential needs. Functional needs are satisfied through the consumption of goods for practical reasons whilst psychological needs are fulfilled through conspicuous consumption of luxury brands. Lastly, experiential needs are fulfilled through internalised consumption (Kapferer, 1997; O'Cass and Frost, 2002; Amatulli and Guido, 2011). The store atmosphere in luxury flagship stores needs to meet customers' needs and motivations and reinforce the brand image (Kotler and Armstrong, 2008). In order to do that, Tungate (2009) states that luxury brands need to increase the authenticity of the product and make customers see its uniqueness and high quality. Therefore, the creation and management of the flagship store environment becomes increasingly important. Furthermore, in their study examining customer satisfaction drivers for the luxury clothing market, Ryding et al. (2016) found that service quality was the most important determinant of customer satisfaction, followed by product craftsmanship and design, country of origin and in-store digital entertainment.

\section{The importance of the shopping experience: store environment}

The importance of the shopping experience is especially evident in the fashion sector due to its hedonic and symbolic properties (Levy, 1959). From an experiential perspective, the physical store is defined as a cognitive and emotional scenario where emotional change occurs; it must create value for customers and generate brand awareness (Spena, et al., 2012). The store design must be able to translate the brand identity from the products and services into the customer experience (Jones et al., 2010). Thus, retail stores are "unique in allowing consumers to touch and feel merchandise and provide instant gratification" [Brynjolfsson et al., (2013), p. 23]. Thus, the store atmosphere is the result of the layout and the environment and it generates specific outcomes in terms of consumers' shopping behaviour (Parsons, 2011; Ballantine et al., 2010).

The store environment creates a holistic cognitive experience based on entertainment, design, customer involvement and sensory attributes (Rigby, 2011; Spena et al., 2012) that must be inspiring and stimulating (Bäckström and Johansson, 2006). Nowadays, a lot of retailers already understand the importance of the consumer shopping experience and 
so continue to search and create new ways to enhance the shopping experience and use this to increase consumer loyalty and obtain a competitive advantage (Kent et al., 2015). The store atmosphere integrates each store environment factor to create a kind of 'space aesthetics', projecting the brand image and encouraging customer purchase behaviours (Bitner, 1992).

In the current retail scenario, markets are more diverse and fragmented and the increasing growth of digital channels has increased the pressure on physical stores. Indeed, some research suggests that traditional physical stores have lost their appeal and decreased in terms of sales (Kozinets et al., 2002). However, the store experience is key in the generation of value perceptions in retailing (Kerin et al., 1992) which necessitates the creation of a superior experience for the consumer. This experience cannot be understood without an appreciation of the role of retail atmospherics to create a more memorable and entertaining shopping experience (Kotler, 1973; Kozinets et al., 2002). The concept of atmospherics was first introduced by Kotler (1973) and defined as the conscious design of space to create certain effects in buyers. The way consumers perceive a store, therefore, relies on the retailer's manipulation of numerous factors, or cues, that stimulate feelings and customer expectations (Newman and Patel, 2004) which can lead to the success or failure of a business (Bitner, 1992). Atmospherics have a direct effect on the customer experience, influencing various psychological and behavioural shopping outcomes such as the increase of the willingness to buy or on the value perceived by consumers in their shopping experiences (Puccinelli et al., 2009; Baker et al., 2009; Babin and Attaway, 2000).

The first classification of atmospherics was developed by Berman and Evans (1995) who divided them into four different categories: external elements, the general interior, the layout and design variables, and the point of purchase and decoration variables. Turley and Milliman (2000) completed this classification with a fifth category named human variables that includes employees and the interaction with other customers in the store. Within these five categories, 57 specific cues were identified. They conceptualised these atmospheric variables as "stimuli leading to some cognitive effect within the individual which, in turn, leads to some behavioural response" [Turley and Milliman, (2000), p.194]. This classification will be used as the theoretical basis of this research. The first groups of stimuli are 'external variables' that include things such as the storefront, entrance, display windows or building architecture. The second category is "general interior variables" with elements like the use of lighting, scents, sounds, use of colour and even the temperature. The 'layout and design' variables include aspects such as the allocation of floor space or fixtures. The 'point of purchase and decoration' category includes product displays or point-of-purchase displays amongst others. Lastly, 'human variables' refers to the influence of other shoppers (customer crowding, privacy) and the influence of retail employees (employee characteristics and employee uniforms).

Following environmental psychology theories, Bitner (1992) established that customers respond to environments holistically. This means that they perceive these individual stimuli but that it is the total configuration of the stimuli that will determine their response to the environment, following a holistic pattern of interdependent stimuli. This research will adopt this holistic approach to the store atmosphere furthering research conducted by Ballantine et al. (2010). Ballantine et al. (2010) found that several atmospheric cues contribute to the excitement of customers and elicit approach behaviours: lighting, sound, space, colour, product display and design of space were mentioned amongst others. For example, the appropriate use of lighting, such as a 
product spotlight, was found to enhance enjoyment and had an influence on the quality perception of the products, whilst sound increased interest and arousal. Also, large and open spaces made consumers feel more comfortable and they preferred a limited colour palette.

\section{Purchase behaviour}

Customers engage in shopping behaviour not only to buy a product but also to experience the service and the shopping experience. The influence of the store environment in shopping behaviour has been widely addressed in previous research. Donovan and Rossiter (1982) introduced the Mehrabian-Russell environmental psychology model based on the stimulus-organism-response paradigm which measures the emotions produced by the shopping environment and their influence on consumers' approach and avoidance behaviours in terms of consumers' attitudes and intentions (Russell and Mehrabian, 1976). This model was expanded in later research to actual purchase behaviour demonstrating that the pleasure induced by store environments is a strong cause for spending extra time and extra money in the store (Donovan et al., 1994). Consistent with these results, Scarpi (2006) found that in specialty apparel stores the environment influences shopping orientation in terms of providing a hedonic or utilitarian shopping experience. Subsequently, the provision of a hedonic shopping experience has an effect on the amount of money that customers spend in the store, the expensiveness of the products and the number of items that they buy. A hedonic shopping experience will also generate more excitement in shoppers according to Ashley et al. (2010). Regarding specific stimuli, previous research has also found that the arousal state produced by music and scent in store environments increases customers' pleasure levels, leading to approach behaviours and satisfaction (Morrison et al., 2011).

Moreover, customer buying behaviours can be divided into impulse purchase behaviour and non-impulse purchase behaviour. Based on Beatty and Ferrel (1998), impulse buying is "a sudden and immediate purchase with no pre-shopping intentions" which is different from unplanned buying. Non-impulse purchase behaviour includes both planned and unplanned purchases. The store atmosphere may influence the utilitarian customer who goes into the store to buy something specific, into buying additional items. Alternatively, customers that go into the store to browse because they like the environment may unexpectedly spend more money as a result of the atmosphere in the store (Sherman et al., 1997). Thus, even in cases where there is no purchase activity associated in the visit to a store, the store atmosphere can influence customers' patronage intention. This influence is derived from a positive brand impression, which contributes to enhanced customer loyalty and consequently generates long-term income. Hence, Mohan et al. (2013) explored the effects of four elements of the store environment on impulse buying behaviour: music, light, layout and employees. They found that all the elements had a positive effect on impulse buying behaviour, but that layout had the most significant effect. However, there is a lack of specific research that relates the store atmosphere in flagship stores with customers' purchase behaviours, including both impulse and non-impulse purchase behaviour. This research will consider these relationships in order to address this gap. 


\section{Methodology}

This article applies an interpretivist, inductive research approach to explore the characteristics and impact of luxury flagship stores on purchase behaviours. The research follows the principles of qualitative research. It allows for reality to be constructed through the researcher's description and/or interpretation and ability to communicate the respondent's reality (Szmigin and Foxall, 2000). Fundamentally it is concerned with understanding, as opposed to causation (Repko, 2008).

A qualitative enquiry was undertaken through 20 semi-structured interviews with a purposive sample consisting of both male and female participants across a broad age range. The objective of the interviews was to explore consumers' experiences in luxury flagship stores located in the UK. The sample selection was made based on the requirement that participants had visited a luxury flagship store in the last year. The interview started with a filter question to ensure all participants met this requirement. Some of the stores visited by the participants were Gucci, Louis Vuitton and Chanel amongst others. Also, in order to classify respondents based on their purchase behaviour in flagship stores, the following question was included: "did you buy something in this store during that visit?". From the total of 20 interviewees, eight participants did not purchase anything during that visit and 12 participants made a purchase. From these 12 participants, five participants engaged in impulse purchase behaviour and seven participants engaged in non-impulse purchase behaviour. Table A1 shows the main demographic characteristics of the sample and details of purchase behaviour.

The interview questions were designed according to the literature previously reviewed. The first part of the interview was focused on the store atmosphere following the classifications outlined by Turley and Milliman (2000). Participants were asked about their experience holistically and about the different groups of atmospheric cues encountered. If participants mentioned any specific element, this was analysed in further detail according to the research design conveyed by Ballantine et al. (2010). The second part of the research explored the relationship between store atmospherics and participants' purchase behaviour. These questions were based on the influence of the shopping environment on purchase behaviour and on the influence of the shopping environment on impulse buying and non-impulse buying. The results were analysed using NVivo software. The topic guide used in the interviews has been included in Table A2.

\section{Results}

The first section of the results is focused on the impact of atmospheric cues on consumers' shopping experiences.

The findings emphasise the importance of external atmospherics in relation to the flagship store, as nine interviewees mentioned the relevance of the 'building' and the presence of the 'logo' on it. Both produced a positive first impression and invited them to enter the store:

"I certainly can see the big logo at a glance (20)."

The 'size' of the store was another important aspect mentioned by seven interviewees. Respondents stated that a large store gave the impression that the retailer had a full range of products and acted as a point of attraction to enter. Lastly, 'window displays' were 
mentioned by three interviewees as an external atmospheric cue that was very influential in their decision to enter the store as a result of their enticing design.

The 'lighting' of the store was the most prominent interior atmospheric cue, mentioned by 16 participants. With regards to the specific effects of lighting in the shopping experience, interviewees reported that it focused their attention on the product, resulting in the product appearing to be more attractive and appealing:

"If the lights are gathered on a product, I will pay more attention to that product (13)."

Lighting also contributed to the creation of a comfortable and suitable atmosphere for different brands. The 'colour scheme' was the second most important atmospheric cue mentioned by participants. The use of a specific colour is normally related to the brand image and its history, such as the Red Valentino shoes mentioned by some participants, which made them feel immersed in the brand's universe. Next, the 'noise and music' cue was considered, as respondents communicated a preference for a quiet atmosphere and soft music. However, respondents noted that music should be consistent with the image of the brand. On the other hand, 'scent' was not considered to be a significant atmospheric cue by the majority of participants, but the minority of participants that discussed this stated that it did influence their shopping experience in the form of approach and avoidance behaviours. Finally, the use of 'carpets' in the store created the impression that the shoes that consumers were trying on were of higher financial value.

The next group of atmospheric cues relate to layout and design variables. The furniture was the primary aspect mentioned by participants, including chairs, sofas, and resting areas to decorate and showcase the products. Indeed, the furniture and the way that it was positioned within the flagship store played an important role in the holistic shopping experience. The resting areas were important because they enabled consumers to relax and continue shopping after a pause, as well as enabling their friends/family to have the ability to rest whilst they browsed. Therefore, the provision of resting areas resulted in an increased time spent in the store as well as a more enjoyable shopping experience.

The fitting rooms also played an important role in the shopping experience, as explained by participants:

"In some stores the fitting rooms are like a small stage. This makes me willing to try on clothes and I may buy them afterwards (20)."

This alludes to a sense of the dramatic and emphasises the role of the fitting rooms in luxury flagship stores in facilitating consumers' escapism and enjoyment. Furthermore, respondents expect to find luxurious and comfortable fitting rooms in luxury retailers' flagship stores and so this is perceived to be a minimum requirement by consumers.

A further aspect mentioned was the spacious design of the flagship store and, in particular, the large area of space allocated to each product, making it feel airy and not too enclosed, resulting in a more satisfying and enjoyable shopping experience for consumers. Point-of-purchase and decoration variables were also explored in the provision of a superior retail experience. The results found that 'product display' was important for respondents for two reasons. Firstly, because it helped them to find the product easily and secondly, because it added perceived financial value to the product:

"There are wide spaces between handbags. One wall may have less than ten handbags, which make me think these handbags are very expensive (11)." 
The use of 'technology' was also mentioned as a way to improve the shopping experience. In particular, the use of in-store tablets helped consumers to find products:

"In the Gucci store, there is a shopping guide to look for the type of product I want (8)."

Also, the provision of free WiFi by the retailer had a positive effect on consumers' satisfaction in their shopping experience.

Lastly, human variables were considered from both employee and customer perspectives. First and foremost, the results found that 'employees' were one of the most important assets in flagship stores. Respondents reported that experiencing a personal service made them feel important:

"Personal service and employee attitude was particularly good (16)."

Furthermore, the recommendations and suggestions from employees had a direct effect on customers' purchase behaviour:

"If the sales person is passionate and gives me a lot of good suggestions, I'm more willing to buy something or to buy more (16)."

Thus, the results found that the sales skills and attitudes of employees had a strong influence on customers' purchase behaviour in flagship stores.

The type of other customers present in flagship stores and their number also made a difference to consumers' shopping experience. In particular, respondents prefer to have a small number of other customers present, consisting of people that are well-presented in how they dress.

The atmospheric cues were also considered as part of the holistic retail experience created for consumers. The most frequent aspects mentioned by respondents about their shopping experience in the flagship store was the 'high quality service', superior 'store atmosphere', 'high status', a 'comfortable' and 'relaxing' experience, and a 'stylish' shopping environment. Moreover, the holistic atmosphere was found to be consistent with the brand image of the different fashion retailers visited and created a positive impression of the brand for consumers. More specifically, aspects such as the interior design and the use of colour were found to be very important in the formulation of a positive brand image.

In order to fulfil the aim of the study, the secondary part of this research explored how the atmospheric cues in luxury flagship stores had an effect on customers' purchase behaviour, differentiating between impulse and non-impulse purchase behaviour.

The results found that the main atmospheric cues that influenced impulse purchase behaviour in flagship stores was the 'employees'; specifically when they provided customers with product information and style suggestions. Participants commented on the flattering 'sales strategies' used by staff:

"When we walked in the store, he commented on my dress great style, your shoes are Valentino, very nice (12)."

This type of sales technique resulted in customers feeling more at ease and made them more willing to follow his advice. The other atmospheric cue that had a significant effect on impulse purchase behaviour was the product display and the lighting. Indeed, the presentation of the products in a luxury setting added perceived financial value to them and resulted in respondents being drawn to them and thereafter more likely to engage in impulse purchase behaviour. In terms of non-impulse purchase behaviour, some 
respondents planned to buy a specific product in advance of visiting the store. In these cases, the flagship store staff helped them to find and buy a specific product.

However, some of the interviewees did not buy anything in their previous visit to a flagship store. Nevertheless, they found the experience to be very enjoyable and emphasised that they would be returning again. The respondents reported that the flagship experience was superior to any other type of store as it had a full range of products available and they received high quality customer service from staff. Furthermore, the possibility of interaction with technological features that cannot be found in other stores, such as virtual mirrors, made the experience enjoyable. Overall, respondents affirmed that:

"If I need buy something in the physical store, I prefer to go to the flagship store, because they have more products, the experience is better and the price is the same (14)."

This indicates that the flagship store environment and the atmospheric cues within it had an impact on the likelihood of consumers returning to the store and re-patronage intentions.

In summary, the most influential atmospheric cues based on the results of the interviews were the service/employees followed by the product display, the layout of space and the design and experience of the fitting rooms. The atmospheric cues and design features had a significant impact on the perceived experience with the brand and on both impulse and non-impulse purchase behaviour.

\section{Discussions and conclusions}

The results found that consumers impressions of flagship stores begins externally, emphasising the importance of the external design variables in creating a favourable first impression and encouraging consumers to enter. The large size, attractive design of the building, as well as a prominent brand logo invites consumers to enter the store. Furthermore, impressive and brand-relevant window displays are key in attracting consumers' attention and persuading them to enter the store, as well as setting the tone for the brand image. The results, therefore, reaffirm the significance of window displays as argued by Pantano (2016) in persuading consumers to enter a store and the importance that consumers place on the aesthetics of the storefront and the window display, but also contribute new findings that emphasise the importance of the holistic design of the storefront and prominence of the logo in persuading customers to enter luxury flagship stores alongside the window display.

Lighting was found to be an influential interior atmospheric cue for many of the interviewees, followed by colour. Indeed the results found that the lighting in a flagship store has an effect on the amount of attention consumers' pay towards products, increasing their appeal, confirming the findings by Ballantine et al. (2010). Furthermore, the colours used in the store had an effect on the perceived brand image and resulted in consumers feeling more immersed in the brand experience. This concurs with research conducted by Tantanatewin and Inkarojrit (2016) that different colour and lighting conditions have a significant effect on both the consumer's impression of space and their perception of the retailer's identity, although this research study was based on banks rather than fashion retail and so the present study implies that these findings are 
transferable to this context. Moreover, in terms of the interior design cues, soft, calming and quiet music was preferred, although it should be in keeping with the brand image, and plush carpets added an aura of luxury and wealth. The importance of having carpets in luxury flagship stores is a novel finding, and highlights the importance of considering luxury flagship stores for research into store atmospherics. Furthermore, the results found that scent was not considered to be a significant atmospheric cue by the majority of participants. This contrasts to previous research by Morrison et al. (2011) who found that scent can have an effect on consumers' emotions, satisfaction levels and increased pleasure levels.

The layout of the flagship store was also considered to be an important atmospheric cue. The availability of comfortable chairs facilitating a refuge and resting area for consumers, as well as their friends and family, resulted in a more pleasurable shopping experience and an increased time spent in the store. This is a novel finding and contributes to the academic literature by stressing the importance of including resting areas in luxury flagship stores in order to enhance consumers' shopping experience and satisfaction levels. Furthermore, the fitting rooms also contributed to a more enjoyable shopping experience, and respondents used theatrical language to describe their expectations and experience in the fitting rooms of luxury flagship stores, likening it to their 'stage'. This indicates a sense of the majestic and the importance of designing the fitting rooms as a place where consumers can transform into an enhanced version of themselves and feel a sense of pride when trying on items. This luxurious and dramatic experience resulted in an increased purchase intention. This is a new finding and therefore a new contribution to the academic literature on flagship stores.

Furthermore, the results found that the display of the products in flagship stores is very important as it directs consumers to key items easily and adds perceived financial value to products. The study also found that one reason why customers would prefer to shop in the flagship store is because it has the full product range available. This supports research conducted by Moore et al. (2010) who found that one of the main roles of the flagship store is to showcase the full product range to customers, making it the "home of the brand'. The present study extends this research by confirming that consumers perceptions of the flagship store having the full product range concurs with the message disseminated by the brand. The use of technology in luxury flagship stores also created a positive experience for consumers and encouraged purchase intention. In particular, the use of tablets in-store enables consumers to find an item that they want easily and read about its key features. This suggests that digital technology is utilised by consumers for practical, utilitarian reasons in luxury flagship stores, as opposed to entertainment reasons as suggested by Ryding et al. (2016).

The results found that employees are one of the most important assets in luxury flagship stores as the service they provide to customers makes them feel important and valued. Thus, these findings support past research studies that service quality is a key contributor of customer satisfaction in a luxury apparel store (Ryding et al., 2016). Furthermore, the recommendations and advice provided by employees had a direct effect on customers' purchase behaviour. This study, therefore, concurs with previous research that consumers shopping for luxury items in stores value the shopping experience and the interactions present in it (Liu et al., 2013).

In terms of the store environment, this study found that consumers prefer luxury flagship stores to consist of a minimal number of other customers and ones that are well-presented in how they dress, which adds to the prestige and luxurious atmosphere of 
the store. This was also important in terms of the design variables, as a large, expansive store resulted in a more satisfying shopping experience for consumers. This study therefore partially agrees with the results found by Alawadhi and Yoon (2016) in that female shoppers have particularly lower shopping intentions in stores that are crowded, but disagrees that this is a gender-specific notion as there were no differences in attitude towards crowding amongst genders and adds a new contribution to the literature highlighting the importance of the presentation of other customers in consumers' satisfaction levels when shopping in luxury flagship stores.

Thus, overall the atmospheric cues in luxury flagship stores contributed to a consistent presentation of the brand and a positive shopping experience for consumers. The most frequent cues mentioned by respondents about their shopping experience in the flagship store were the 'high quality service', superior 'store atmosphere', 'high status', the 'comfortable' and 'relaxing' experience, and the 'stylish' shopping environment. Hence, the atmospheric cues facilitated a positive experience with the brand for consumers and a created a favourable brand identity. This study, therefore, agrees with previous research that the flagship store is a successful branding tool that showcases the brand's identity and solidifies it in the minds of consumers (Manlow and Nobbs, 2013). Furthermore, this study concurs with Manlow and Nobbs (2013) in their findings that, by shopping in the flagship store, the status of the brand become the status of the consumer, which was achieved through the sales assistants and their communication with customers, putting them at ease and treating them with respect and prestige. However, the present study builds upon this by arguing that luxury flagship stores also have a significant effect on customers' purchase behaviour facilitated by the atmospherics and the way that they are designed. Hence, the study contributes to the academic literature by emphasising the necessity of flagship stores as part of a global marketing and management strategy to enter new markets as they influence consumers' impulse and non-impulse purchase behaviour through the delivery of a superior experience.

Hence, this study found that the luxury flagship store has an effect on consumers' purchase behaviour. In particular the sales assistants and the flattering sales techniques that they employed had a positive effect on both impulse purchase behaviour and non-impulse purchase behaviour. Furthermore, the product display and the lighting also had an impact on impulse purchase behaviour. Finally, the results also found that the flagship store's holistic environment and atmospheric cues had an impact on the likelihood of consumers returning to the store, and therefore emphasises the key use of luxury flagship stores for increasing customers' repatronage intentions.

\section{Academic contribution}

This paper builds on the study conducted by Moore et al. (2010), who investigated the role of flagship stores as a market entry method for luxury retailers, as it explores how luxury retailers can employ a superior experience through the atmospherics in their flagship stores and how this can influence purchase behaviour. Whereas Moore et al. (2010) focused on the role of luxury flagship stores from a company perspective, the present study explored what atmospheric and design cues make flagship stores successful from a customer's perspective and how these atmospheric cues have an effect on their experience with, and view of, the brand as well as their purchase behaviour. In this 
respect, our research also builds on and extends the theories that relate the store environment with impulse purchase behaviour, filling the gap indicated by Mohan et al. (2013) regarding the influence of aesthetics and appearance of the store on impulse purchase behaviour. Finally, this research considers the differences between impulse purchase behaviour and non-impulse purchase behaviour, and how the atmospheric cues can have an impact on each type of behaviour, which is not considered by previous studies such as Ballantine et al. (2015) and Moore et al. (2010), and found that product display and lighting had more of an impact on impulse purchase behaviour, thus providing a new contribution to the academic literature.

\section{Limitations and future research}

The most notable limitation of this research is the scale of it, as, although several different global luxury brand flagship stores were analysed, it was only done so in one country, and so may be limited in terms of standardisation and generalisation of the findings. In further research, there is an opportunity to extend the study to a larger number of global luxury retailers in order to confirm these findings on a wider and more solid base.

\section{References}

Alawadhi, A. and Yoon, S-Y. (2016) 'Shopping behavioral intentions contributed by store layout and perceived crowding: an exploratory study using computer walk-through simulation', Journal of Interior Design, Vol. 41, No. 4, pp.29-46.

Amatulli, C. and Guido, G. (2011) 'Determinants of purchasing intention for fashion luxury goods in the Italian market', Journal of Fashion Marketing and Management, Vol. 15, No. 1, pp.123-36.

Arrigo, E. (2015) 'The role of the flagship store location in luxury branding. An international exploratory study', International Journal of Retail \& Distribution Management, Vol. 43, No. 6, pp.518-537.

Ashley, C., Ligas, M. and Chaudhuri, A. (2010) 'Can hedonic store environments help retailers overcome low store accessibility?', The Journal of Marketing Theory and Practice, Vol. 18, No. 3, pp.249-262.

Babin, B.J. and Attaway, J.S. (2000) 'Atmospheric affect as a tool for creating value and gaining share of customer', Journal of Business Research, Vol. 49, No. 2, pp.91-99.

Bäckström, K. and Johansson, U. (2006) 'Creating and consuming experiences in retail store environments: comparing retailer and consumer perspectives', Journal of Retailing and Consumer Services, Vol. 13, No. 6, pp.417-430.

Baker, J., Grewal, D. and Parasuraman, A. (2009) 'The influence of store environment on quality inferences and store image', Journal of the Academy of Marketing Science, Vol. 22, No. 4, pp.328-339.

Ballantine, P.W., Jack, R. and Parsons, A.G. (2010) 'Atmospheric cues and their effect on the hedonic retail experience', International Journal of Retail \& Distribution Management, Vol. 38, No. 8, pp.641-653.

Ballantine, P.W., Parsons, A. and Comeskey, K. (2015) 'A conceptual model of the holistic effects of atmospheric cues in fashion retailing', International Journal of Retail \& Distribution Management, Vol. 43, No. 6, pp.503-517.

Beatty, S.E. and Ferrell, M.E. (1998) 'Impulse buying: modeling its precursors', Journal of Retailing, Vol. 74, No. 2, pp.169-191. 
Berman, B. and Evans, J.R. (1995) Retail Management: A Strategic Approach, Prentice-Hall, Inc., Englewood Cliffs.

Bitner, M.J. (1992) 'Servicescapes: the impact of physical surroundings on customers and employees', Journal of Marketing, Vol. 56, No. 2, pp.57-71.

Blázquez, M. (2014) 'Fashion shopping in multichannel retail: the role of technology in enhancing the customer experience', International Journal of Electronic Commerce, Vol. 18, No. 4, pp.97-116.

Brengman, M. and Willems, K. (2003) 'Determinants of fashion store personality: a consumer perspective', Journal of Product and Brand Management, Vol. 18, No. 5, pp.346-55.

Brynjolfsson, E., Hu, Y.J. and Rahman, M.S. (2013) 'Competing in the age of omni-channel retailing', MIT Sloan Management Review, Vol. 54, No. 4, pp.23.

Chevalier, M. and Mazzalovo, G. (2012) Luxury Brand Management: A World of Privilege, John Wiley and Sons, Singapore.

Choi, T.M. (2014) Fashion Branding and Consumer Behaviour, Springer, Heidelberg.

Dolbec, P. and Chebat, J. (2013) 'The impact of a flagship vs. a brand store on brand attitude, brand attachment and brand aquity', Journal of Retailing, Vol. 89, No. 4, pp.460-466.

Donovan, R. and Rossiter, J. (1982) 'Store atmosphere: an environmental psychology approach', Journal of Retailing, Vol. 58, No. 1, pp.34-57.

Donovan, R.J., Rossiter, J.R., Marcoolyn, G. and Nesdale, A. (1994) 'Store atmosphere and purchasing behavior', Journal of Retailing, Vol. 70, No. 3, pp.283-294.

Heine, K. and Phan, M. (2011) 'Trading-up mass-market goods to luxury products', Australasian Marketing Journal (AMJ), Vol. 19, No. 2, pp.108-114.

John, D.R. (2016) 'Customer-based strategic brand management: past progress and future challenges', AMS Review, Vol. 6, No. 1, pp.23-32.

Jones, P., Comfort, D., Clarke-Hill, C. and Hillier, D. (2010) 'Retail experience stores: experiencing the brand at first hand', Marketing Intelligence \& Planning, Vol. 28, No. 3, pp.241-248.

Kapferer, J. (2008) The New Strategic Brand Management, 1st ed., Kogan Page, London.

Kapferer, J.N. (1997) 'Managing luxury brands', Journal of Brand Management, Vol. 4, No. 4, pp.251-60.

Kapferer, J.N. and Bastien, V. (2008) The Luxury Strategy: Break the Rules of Marketing to Build the Luxury Brand, MPG Books, Bodmin, Cornwall.

Kapferer, J.N. and Bastien, V. (2012) The Luxury Strategy, 2nd ed., Kogan Page Limited, London.

Kent, A., Dennis, C., Blazquez, M., Helberger, E. and Brakus, J. (2015) 'Branding, marketing, and design: experiential in-store digital environments', in Successful Technological Integration for Competitive Advantage in Retail Settings, pp.1-22, IGI Global.

Kent, T. and Brown, R. (2009) Flagship Marketing: Concepts and Places, Routledge, London.

Kerin, R., Ambuj, J. and Howard, D. (1992) 'Store shopping experience and consumer price quality - value perceptions', Journal of Retailing, Vol. 68, No. 4, pp.376-397.

Kotler, P. (1973) 'Atmospherics as a marketing tool', Journal of Retailing, Vol. 49, No. 4, pp.48-64.

Kotler, P. and Armstrong, G. (2008) Principles of Marketing, 12th ed., Prentice Hall International, Pearson Education.

Kozinets, R.V., Sherry, J.F., DeBerry-Spence, B., Duhachek, A., Nuttavuthisit, K. and Storm, D. (2002) 'Themed flagship brand stores in the new millennium', Journal of Retailing, Vol. 78, No. 1, pp.17-29.

Levy, S. (1959) 'Symbols for sale', Harvard Business Review, Vol. 37, No. 4, pp.117-124.

Liu, X., Burns, A. and Hou, Y. (2013) 'Comparing online and in-store shopping behavior towards luxury goods', International Journal of Retail \& Distribution Management, Vol. 41, Nos. 11-12, pp.885-900. 
Manlow, V. and Nobbs, K. (2013) 'Form and function of luxury flagships: an international exploratory study of the meaning of the flagship store for managers and customers', Journal of Fashion Marketing and Management: An International Journal, Vol. 17, No. 1, pp.49-64.

Mohan, G., Sivakumaran, B. and Sharma, P. (2013) 'Impact of store environment on impulse buying behavior', European Journal of Marketing, Vol. 47, No. 10, pp.1711-1732.

Moore, C.M., Doherty, A.M. and Doyle, S.A. (2010) 'Flagship stores as a market entry method: the perspective of luxury fashion retailing', European Journal of Marketing, Vol. 44, Nos. 1-2, pp.139-161.

Morrison, M., Gan, S., Dubelaar, C. and Oppewal, H. (2011) 'In-store music and aroma influences on shopper behaviour and satisfaction', Journal of Business Research, Vol. 64, No. 6, pp.558-564.

Newman, A.J. and Patel, D. (2004) 'The marketing directions of two fashion retailers', European Journal of Marketing, Vol. 38, No. 7, pp.770-89.

O'Cass, A. and Frost, H. (2002) 'Status brands: examining the effects of non-product-related brand associations on status and conspicuous consumption', Journal of Product \& Brand Management, Vol. 11, No. 2, pp.67-88.

Pantano, E. (2016) 'Engaging consumer through the storefront: evidences from integrating interactive technologies', Journal of Retailing and Consumer Services, Vol. 28, pp.149-154.

Parsons, A.G. (2011) 'Atmosphere in fashion stores: do you need to change?', Journal of Fashion Marketing and Management: An International Journal, Vol. 15, No. 4, pp.428-445.

Phau, I. and Prendergast, G. (2000) 'Consuming luxury brands: the relevance of the 'rarity principle', The Journal of Brand Management, Vol. 8, No. 2, pp.122-138.

Puccinelli, N., Goodstein, R., Grewal, D., Price, R., Raghubir, P. and Stewart, D. (2009) 'Customer experience management in retailing: understanding the buying process', Journal of Retailing, Vol. 85, No. 1, pp.15-30.

Rath, P.M., Petrizzi, P. and Gill, P. (2012) Marketing Fashion: A Global Perspective, Fairchild, New York.

Repko, A.F. (2008) Interdisciplinary Research, Process and Theory, Sage, London.

Rigby, D. (2011) 'The future of shopping', Harvard Business Review, Vol. 89, No. 12, pp.65-76.

Russell, J.A. and Mehrabian, A. (1976) 'Some behavioral effects of the physical environment', in Wapner, S., Cohen, S. and Kaplan, B. (Eds.): Experiencing the Environment, pp.5-18, Plenum, New York.

Ryding, D., Vignali, G., Caratù, M., Wang, Y. and Carey, R. (2016) '21st century luxury fashion retailers' marketing strategies for customer satisfaction: UK perspective', International Journal of Business and Globalization, Vol. 16, No. 1, pp.79-103.

Scarpi, D. (2006) 'Fashion stores between fun and usefulness', Journal of Fashion Marketing and Management: An International Journal, Vol. 10, No. 1, pp.7-24.

Sherman, E., Mathur, A. and Smith, R.B. (1997) 'Store environment and consumer purchase behavior: mediating role of consumer emotions', Psychology \& Marketing, Vol. 14, No. 4, pp.361-78.

Spena, T., Caridà, A., Colurcio, M. and Melia, M. (2012) 'Store experience and co-creation: the case of temporary shop', International Journal of Retail \& Distribution Management, Vol. 40, No. 1, pp.21-40.

Szmigin, I. and Foxall, G. (2000) 'Interpretive consumer research: how far have we come?', Qualitative Market Research: An International Journal, Vol. 3, No. 4, pp.187-197. 
Tantanatewin, W. and Inkarojrit, V. (2016) 'Effects of color and lighting on retail impression and identity', Journal of Environmental Psychology, Vol. 46, pp.197-205.

Tungate, M. (2009) Luxury World: The Past, Present and Future of Luxury Brands, Kogan Page, London and Philadelphia.

Turley, L.W. and Milliman, R.E. (2000) 'Atmospheric effects on shopping behavior: a review of the experimental evidence', Journal of Business Research, Vol. 49, No. 2, pp.193-211.

Urde, M. (2013) 'The corporate brand identity matrix', Journal of Brand Management, Vol. 20, No. 9, pp.742-761.

\section{Appendix}

Table A1 Sample demographics and purchase behaviour

\begin{tabular}{lccccc}
\hline Interviewee & Age & Gender & Duration & $\begin{array}{c}\text { Purchased in } \\
\text { flagship store }\end{array}$ & $\begin{array}{c}\text { Impulse buying vs. } \\
\text { non-impulse buying }\end{array}$ \\
\hline 1 & 23 & Female & $18 \mathrm{mins}$ & No & - \\
2 & 25 & Female & $35 \mathrm{mins}$ & Yes & non- impulse \\
3 & 26 & Female & $37 \mathrm{mins}$ & Yes & impulse \\
4 & 27 & Female & $23 \mathrm{mins}$ & Yes & non-impulse \\
5 & 30 & Female & $20 \mathrm{mins}$ & Yes & impulse \\
6 & 31 & Male & $17 \mathrm{mins}$ & Yes & non-impulse \\
7 & 24 & Male & $20 \mathrm{mins}$ & Yes & non-impulse \\
8 & 33 & Male & $15 \mathrm{mins}$ & No & - \\
9 & 26 & Male & $16 \mathrm{mins}$ & No & - \\
10 & 38 & Female & $22 \mathrm{mins}$ & Yes & non-impulse \\
11 & 23 & Female & $35 \mathrm{mins}$ & Yes & impulse \\
12 & 22 & Female & $18 \mathrm{mins}$ & Yes & non-impulse \\
13 & 30 & Female & $20 \mathrm{mins}$ & Yes & non-impulse \\
14 & 24 & Female & $15 \mathrm{mins}$ & No & - \\
15 & 25 & Male & $25 \mathrm{mins}$ & Yes & impulse \\
16 & 28 & Female & $23 \mathrm{mins}$ & No & - \\
17 & 26 & Female & $15 \mathrm{mins}$ & No & - \\
18 & 31 & Female & $18 \mathrm{mins}$ & No & - \\
19 & 25 & Male & $18 \mathrm{mins}$ & Do not remember & - \\
20 & 26 & Female & $30 \mathrm{mins}$ & Yes & impulse \\
\hline & & & & &
\end{tabular}


Table A2 Topic guide for interviews

\begin{tabular}{|c|c|}
\hline \multicolumn{2}{|l|}{ Topic guide } \\
\hline \multicolumn{2}{|c|}{ Store atmosphere dimensions (Turley and Milliman, 2000; Ballantine et al., 2010) } \\
\hline $\begin{array}{l}\text { External cues (i.e., window } \\
\text { display/building) }\end{array}$ & $\begin{array}{l}\text { What do you think about the external } \\
\text { atmosphere of the store? }\end{array}$ \\
\hline & How does it affect your shopping experience? \\
\hline $\begin{array}{l}\text { Interior cues (i.e., } \\
\text { lights/sound/wallpaper/flooring) }\end{array}$ & $\begin{array}{l}\text { Can you provide some details of the aspects } \\
\text { that influenced your experience inside the } \\
\text { store? }\end{array}$ \\
\hline $\begin{array}{l}\text { Layout and design cues (i.e., } \\
\text { aisles/space/furniture/fitting room) }\end{array}$ & $\begin{array}{l}\text { How did the layout and design influence your } \\
\text { shopping experience? }\end{array}$ \\
\hline $\begin{array}{l}\text { Point of purchase and decoration displays } \\
\text { (i.e., payment technology/product } \\
\text { display/screen advertising/ipad) }\end{array}$ & $\begin{array}{l}\text { How did the external atmosphere of the store } \\
\text { have an effect on your shopping experience? }\end{array}$ \\
\hline \multirow[t]{2}{*}{$\begin{array}{l}\text { Human variables (i.e., staff skills, } \\
\text { customer service) }\end{array}$} & $\begin{array}{l}\text { How did human variables, such as sales } \\
\text { assistants, influence your shopping experience? }\end{array}$ \\
\hline & $\begin{array}{l}\text { How did human variables, such as other } \\
\text { shoppers, influence your shopping experience? }\end{array}$ \\
\hline
\end{tabular}

Holistic store atmosphere (Bitner, 1992)

- Overall, how was your shopping experience considering all factors together?

- Do you think the store atmosphere suits the brand image of the retailer? Why/why not? (Moore et al., 2010).

- How do these atmospheric cues relate to each other? (Bitner, 1992).

- Did your image of the brand change after visiting the flagship store? Why/why not? (Bitner, 1992).

- What element(s) in the store environment do you prefer and why? (Ballantine et al., 2010).

- What element(s) would you want have in the store in the future?

Impulse purchase behaviour (Mohan et al., 2013; Parsons, 2010)

- What elements of the store atmosphere contributed to your impulse purchase behaviour?

- How did these environmental factors prompt you to purchase?

Non-impulse purchase behaviour (Donovan et al., 1994, Parsons, 2010)

- What atmospheric element(s) encouraged you to purchase?

- What elements of the store's atmosphere contributed to your decision to purchase? (Ballantine et al., 2010).

- What are the main differences between this flagship store's atmosphere compared to other brands? (Moore et al., 2010; Ashley et al., 2010).

- What type of shopping experience would you like to have in a luxury flagship store? (Ballantine et al., 2010). 